\title{
The effects of multipotent mesenchymal stromal cells on mouse brain slices at their co-culture in an in vitro model of periventricular leukomalacia
}

\author{
O. Tsupykov ${ }^{1,2}$, I. Lushnikova ${ }^{1}$, A. Ustymenko ${ }^{2}$, V. Kyryk ${ }^{2}$, Y. Nikandrova ${ }^{1}$, M. Patseva ${ }^{1}$, \\ K. Yatsenko', G. Butenko' ${ }^{2}$, G. Skibo ${ }^{1,2}$ \\ ${ }^{1}$ Bogomoletz Institute of Physiology National Academy of Sciences of Ukraine, Kyiv; \\ ${ }^{2}$ State Institute of Genetic and Regenerative Medicine National Academy of Medical Sciences of \\ Ukraine, Kyiv; e-mail: tsupykov@gmail.com
}

\begin{abstract}
Multipotent mesenchymal stromal cells (MMSCs) demonstrated a measurable therapeutic effect following transplantation into animal models of periventricular leukomalacia $(P V L)$, brain white-matter degeneration resulting from hypoxic-ischemic incidents and/or inflammation. However, the mechanisms by which transplanted MMSCs promote cell survival and/or functional recovery remain indeterminate. In this work we used organotypic brain slices for PVL model in vitro (PVLmiv) subjecting cultures to oxygen-glucose deprivation (OGD) and endotoxin lipopolysaccharide (LPS). This approach allowed us to simulate important pathogenic factors both responsible for PVL, hypoxic-ischemic component and inflammation. Based on the cell viability and the glial reaction, we evaluated distant effects of MMSCs on brain slices with PVLmiv in the non-contact co-culture. Cell viability was assessed by the measurement of cytoplasmic enzyme lactate dehydrogenase ( $L D H)$ released into the culture medium. Glial reaction in the periventricular regions of slices was analyzed immunochistochemically using specific antibodies to glial markers of oligodendrocytes, astrocytes and microglia (Rip, GFAP and Iba-1, respectively). We showed that the PVLmiv resulted in a significant release of the cytosolic enzyme LDH into medium demonstrating substantial cell damage. A decrease of Rip-immunoreactivity indicated deterioration within oligodenrocytic population of cells, while an increase in GFAP and Iba-1 immunoreactivity reflected pronounced astro- and microgliosis. The presence of MMSCs in the co-culture diminished PVLmiv effects improving cell viability, preventing degradation of oligodendocytes and extensive astro- and microgliosis in brain slices. Our data suggest that protective capacity of MMSCs can be executed distantly most likely via released biomodulatory compounds.

Key words: periventricular leukomalacia; brain slice culture; oxygen-glucose deprivation; lipopolysaccharide; multipotent mesenchymal stromal cells.
\end{abstract}

\section{INTRODUCTION}

Periventricular leukomalacia (PVL) is a form of brain injury provoked mainly by hypoxicischemic incidents and/or inflammatory response within white-matter of highly vulnerable brain of newborn, and tightly linked with the preterm childbirth, maternal infections and other labor/pregnancy complications. It is characterized by overt focal necrosis and death of oligodendrocytes - cells responsible for neuronal axon myelination - and astro- and microgliosis in the periventricular zones of the brain [1, 2]. PVL leads to distortion of cerebral signaling, and is responsible for the problems in motor control, delay in the physical, intellectual and emotional development, what often reveals as cerebral palsy or epilepsy later in life [1, $3,4]$. The exact pathogenic mechanisms of PVL and ways of their correction are studied insufficiently.

Contemporary neonatal pharmaceutical therapy of central nervous system (CNS) pathologies remains to be imperfect and hindered by persistent risk to disrupt complex

(C) O. Tsupykov, I. Lushnikova, A. Ustymenko, V. Kyryk, Y. Nikandrova, M. Patseva, K. Yatsenko, G. Butenko, G. Skibo 
relationship of compensatory-adaptive processes at early stages of body development, and to cause additional complications interfering with further drug treatment [4]. Therefore, universal drug-free approaches in the therapy of CNS diseases, including PVL, are the focus of the great interest in extensive studies worldwide.

Stem cell (SCs) technology is considered to be a new promising tool for the effective treatment of CNS disorders [5,6]. Numerous studies have demonstrated that SCs transplantated into the site of injury favored the recovery of damaged tissue via differentiation into specific cell type and production of the biomodulators (growth factors, cytokines and immunomodulators) essential for cell survival, reduction of inflammation and maintenance of tissue homeostasis [5, 7-9]. However, more research is required to better understand mechanisms of transplanted SCs effects.

Aimed to achieve higher fidelity of SCs therapy, many experiments are carried out to evaluate full potency of multipotent mesenchymal stromal cells (MMSCs). MMSCs not only have a tropism for the injured zone in the brain but also show strong immunomodulatory potential suppressing inflammation and favoring recovery of function [10]. Such promising neuroprotective effect from MMSCs transplantation was shown, particularly, in PVL animal model [6, 11]. However, it remains unclear if this positive effect is mediated by actual presence MMSCs in the tissue or by distant modulation via released bioactive factors.

In this study, we used PVL model in organotypic brain slices to evaluate the protective potential of adipose-derived MMSCs in noncontact co-culture.

\section{METHODS}

All experiments were performed in accordance with international principles of the European Convention for the Protection of vertebrate animals used for experimental and other scientific purposes (European convention, Strasburg, 1986), Article 26 of the Law of Ukraine "On protection of animals from cruelty" (21.02.2006) and all norms of bioethics and biosafety.

\section{Organotypic brain slice culture of newborn mice and co-culture with MMSCs}

Brain slice cultures were obtained from FVB mice of postnatal day 7. After rapid decapitation of animal, the brain was removed, divided into two parts through the median line and using a tissue chopper (Mcllwain, GB) cut into 350 microns thick frontal slices $(350 \mathrm{~mm})$, which included the corpus callosum (from bregma 1.10 to bregma 0.10). Slices from indicated zone of each brain hemisphere were chosen for culturing (Fig. 1). We analyzed the area of brain slice

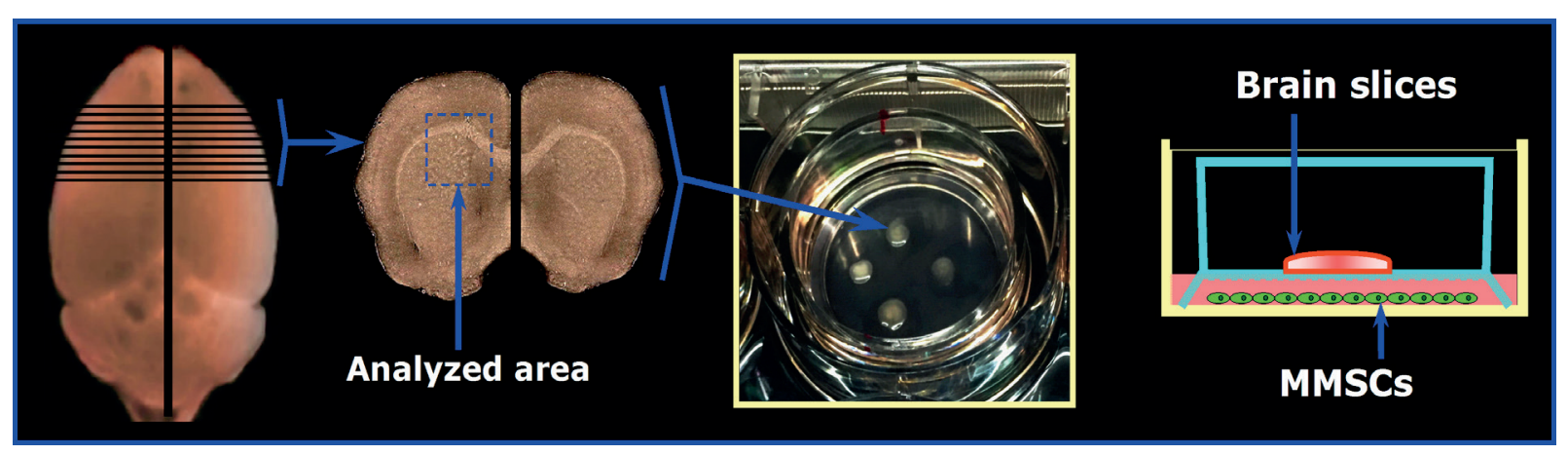

Figure 1. Scheme of obtaining of organotypic brain slice culture and non-contact co-culture with MMSCs. Isolated brain of postnatal mouse was divided into two parts on the median line and cut into frontal slices. Brain slices were transferred onto inserts with porous semitransparent membranes for culturing. For non-contact co-culture the inserts with brain slice cultures were placed into the 6-well plates with adherent culture of MMSCs. Analyzed area is shown by the dashed square 
culture containing the cortex, corpus callosum and periventricular region.

Brain slices were cultured on the gasliquid interface on porous Millicell CM inserts (Millipore, USA) placed into 6-well culture plates in a $\mathrm{CO}_{2}$ incubator with $5 \% \mathrm{CO}_{2}$ at $35{ }^{0} \mathrm{C}$. The culture medium contained $50 \%$ MEM, $25 \%$ Hanks balanced salt solution, 25 $\%$ inactivated horse serum, $10 \mathrm{mM}$ Tris, $2 \mathrm{mM}$ $\mathrm{NaHCO}_{3}, 12.5 \mathrm{mM}$ HEPES, $15 \mathrm{mM}$ glucose, $100 \mathrm{U} / \mathrm{ml}$ penicillin, $100 \mu \mathrm{g} / \mathrm{mL}$ streptomycin (all - Sigma-Aldrich, USA) at $\mathrm{pH} 7.2$, and was changed on the second day of incubation and then twice a week. The slices were cultured for 12 days before PVLmiv and MMSCs co-culture.

For non-contact co-culture, immediately after PVLmiv, inserts with brain slices were transferred to other 6-well plates with earlier adhered MMSCs $\left(4 \times 10^{4}\right.$ cells per well) The porous semitransparent membrane of insert was permeable to soluble factors, but prevented direct cell-to-cell contact. The co-cultures were incubated for $48 \mathrm{~h}$ at $+35{ }^{\circ} \mathrm{C}$ (Fig. 1).

\section{Obtaining of multipotent mesenchymal stromal cells from adipose tissue of mice}

Adipose tissue of FVB mice was used to obtain multipotent mesenchymal stromal cells (MMSCs). Subcutaneous inguinal fat pads were harvested after euthanasia of mice under sterile conditions. Isolated adipose tissue was cut into $1-2-\mathrm{mm}^{3}$ pieces, washed with $\mathrm{Ca}-\mathrm{Mg}$-free phosphate-buffered solution (PBS) (HyClone, USA) and digested for 2.5 hours at $37{ }^{\circ} \mathrm{C}$ with $0.1 \%$ collagenase I (Sigma, USA). At the end of this procedure, collagenase was inactivated by adding Nutrient Medium (DMEM-HG, Sigma) containing $10 \%$ of fetal bovine serum (FBS) (HyClon, USA). After centrifugation the whole suspension of cells $5 \mathrm{~min}$ at $300 \mathrm{xg}$, the supernatant was discarded and the pellet (known as stromal vascular fraction-SVF) was resuspended in DMEM-HG medium containing $10 \% \mathrm{FBS}$, penicillin $100 \mathrm{U} / \mathrm{ml}$, streptomycin $100 \mu \mathrm{g} / \mathrm{ml}, 1: 100$ non-essential amino acids (all Sigma-Aldrich, USA) and seeded to T25 culture flask (Sarstedt, USA) at density $4 \times 10^{3} \mathrm{cells} / \mathrm{cm}^{2}$ for cultivation. Cells grown in a $\mathrm{CO}_{2}$ incubator at $37{ }^{\circ} \mathrm{C}$ and $5 \% \mathrm{CO}_{2}$ humidified atmosphere.

After $24 \mathrm{~h}$ non-adherent cellular debris were discarded and adherent adipose-derived stromal cells washed with PBS. Nutrient media was replaced every 2-3 days. Passaging was carried out at reaching $80 \%$ confluence using $0.05 \%$ trypsin-versene solution. At passage 2 cells were transferred into 6-well tissue culture plates (Sarstedt, USA) for further co-cultivation with brain slices onto cell culture inserts.

Phenotypic characteristics of cultured MMSCs were determined by flow cytometry using BD FACSAria cell sorter (BD Bioscience, USA) with fluorochrome-conjugated rat antimouse monoclonal antibodies CD44 (BD Bioscience, Cat. \#553134), CD73 (BD Bioscience, Cat. \#550741), CD90 (BD Bioscience, Cat. \#551401), CD34 (BD Bioscience, Cat. \#560230), CD117 (BD Bioscience, Cat. \#561074), CD45 (Thermo Scientific, Cat. \#MA1-10233), at a working concentration of $0.5 \mu \mathrm{g} / \mathrm{ml}$. To correct fluorescence spectral overlap compensation in multiparameter analysis we used control cell samples without of antibodies (unstained control), samples with each antibody alone (single-stained controls) and samples with a combination of several antibodies without one (fluorescence minus one - FMO controls). The isotype control was used to determine the level of non-specific background binding of antibodies. The viability of MMSCs was determined by 7-aminoactinomycin D. Data were analyzed using BD FACSDiva 6.2.1 software (BD Bioscience, USA).

To test the osteogenic capacity cultures were treated for 21 days with osteogenic differentiation medium containing $10^{-7} \mathrm{M}$ dexamethasone (Sigma, USA), 0,1 mM ascorbic acid 2-phosphate (Sigma, USA), $10 \mathrm{mM}$ $\beta$-glycerophosphate (Sigma, USA) and $10 \%$ FBS in DMEM-HG. The osteogenic medium was replaced every 2-3 days. After differentiation, the cells were stained with Alizarin Red S to detect calcium deposits. 
Modeling of periventricular leukomalacia on organotypic brain slice culture of mice

Periventricular leukomalacia was modeled by oxygen-glucose deprivation (OGD) and reoxygenation of the brain slices, followed by addition of endotoxin lipopolysaccharide (LPS) into culture medium to mimic the process of inflammation. For the OGD, slices on inserts were placed into special chamber where the gas atmosphere contained $95 \%$ nitrogen and $5 \%$ $\mathrm{CO}_{2}$, while liquid medium contained PBS, 12.5 $\mathrm{mM}$ Hepes and $15 \mathrm{mM}$ D-sucrose substituting glucose. After $30 \mathrm{~min}$ of OGD slices were washed twice and returned to normal culture conditions with adding LPS for 48 hours (100 ng/ml) (L4130, Sigma-Aldrich, USA). This LPS concentration $(100 \mathrm{ng} / \mathrm{ml})$ was selected as the optimal of the three examined concentration (10, 100 and 1000 $\mathrm{ng} / \mathrm{ml}$ ) in the pilot LDH-testing of slices damage.

\section{Lactate dehydrogenase (LDH) assay}

Analysis of $\mathrm{LDH}$ relative level in the culture medium was performed by colorimetric method. During the injury of cell membrane, cytosolic enzyme LDH releases in the culture medium and indicating the degree of cell damage. The color intensity is directly proportional to the amount of the LDH in the culture medium and inversely proportional to cell viability in the culture.

To determine the changes in the relative amount of cytosolic LDH in culture medium in response to the PVL modeling or PVL and MMSCs co-culture, $200 \mu \mathrm{l}$ of culture medium was collected into 24well plate at 48 hours after impact. Samples were collected in duplicates. CytoTox Non-Radioactive Cytotoxicity Assay kit (Promega, USA) was utilized for the colorimetric method that was performed as follows: the reaction was initiated by adding $200 \mu \mathrm{l}$ of substrate in each well and incubated at room temperature in the darkness for 30 minutes; the reaction was terminated by addition of $200 \mu 1$ Stop Solution.

Optical density of the samples was measured with a spectrophotometer uniSPEC 2 ( $L L G$, Germany) at wavelength of 492 $\mathrm{nm}$. We determined the average values of duplicates for each well. As controls we used: 1 - culture medium from the wells without organotypic culture (optical density value of which was subtracted from that of obtained from experimental wells); 2 - culture medium from the well with untreated PVL and MMSCs cultures. Changes in the relative LDH amount in culture medium was expressed in arbitrary units that represent units of solution optical density normalized to the tissue area in the respective well. The values were normalized to the control.

\section{Immunohistochemical staining of organotypic brain slice cultures}

Brain slice cultures were fixed with $4 \%$ solution of paraformaldehyde in $0.1 \mathrm{M}$ PBS. Fixed slices were kept in blocking non-specific binding of proteins solution containing $0.1 \mathrm{M}$ PBS (pH 7.4), $0.5 \%$ bovine serum albumin (BSA) and $0.3 \%$ Triton X-100 (Sigma-Aldrich, USA). The incubation of slices in the primary antibodies solution lasted for 12 hours at $+4{ }^{0} \mathrm{C}$. We used the following primary antibodies: anti-GFAP (a marker of astrocytes) 1: 1500 (Dako Cytomation, Denmark), antiIba-1 (marker of microglia) 1: 1000 (Wako, Japan), Anti-Rip (marker of oligodendrocytes) 1: 200 (Abcam, USA). Relevant secondary antibodies, conjugated with fluorochrome AlexaFluor (Invitrogen, USA), visualized primary antibodies. Stained organotypic brain slice cultures were embedded in a drop of ImmuMount ${ }^{\mathrm{TM}}$ mounting medium (Thermo Scientific, USA). Immunohistochemically stained slice cultures were studied using confocal scanning microscope FV1000-BX61WI (Olympus, Japan).

Quantitative image analysis was carried out using the Image J software (National Institutes of Health, USA). The intensity and area of fluorescence marker were measured by automatic calculation of the average value of gray within the measurement threshold. The results were presented as integrated density of fluorescence in arbitrary units, which are equal to the fluorescence intensity multiplied by area of fluorescence (excluding the integrated density of the background fluorescence). 


\section{Statistical analysis}

Statistical analysis was performed using the Origin Pro 8.5 software (OriginLab Corp., USA). Data sampling included the results obtained from 3 experiments. The results are shown as mean from four values $(n=4)$ in each experimental group \pm standard error of the mean (SEM). The data were characterized by normal distribution, the statistical probability of differences was determined by paired Student t-test; the differences were considered significant at $\mathrm{P}<0.05$.

\section{RESULTS}

According to the minimal criteria of the International Society for Cellular Therapy (ISCT) mesenchymal stem cells must meet the following properties: plastic-adherent in standard culture conditions; high expression of CD105, CD73 and CD90, and lack expression of CD45, CD34, CD14 or CD11b, CD79a or CD19 and HLA-DR surface molecules; must differentiate to osteoblasts, adipocytes and chondroblasts in vitro [12]. In our study the phenotypic analyses of adipose-derived MMSCs showed a high level of mesenchymal markers (CD44, CD73, CD90) expression, while the relative content of cells expressing hematopoietic markers CD45 and CD117 was less than $2 \%$ (data non shown). Multilineage differentiation capacity of adipose-derived MMSCs was confirmed by effective directed osteogenic differentiation.

\section{Viability assessment by $\mathrm{LDH}$}

Spectrophotometric analysis showed that 48 hours after $30 \mathrm{~min}$ OGD treatment and LPS adding in the culture medium (PVLmiv) the relative LDH level increased by 4.3 times comparing to the control slice cultures (Fig. 2). In contrast, in the presence of MMSCs, LDH level in co-culture medium was considerably lower than under PVLmiv (namely, 2.5 times).

Thus, the data revealed the PVLmiv resulted in a significant release of the cytosolic enzyme LDH in culture medium, and these effects were ameliorated to a significant extent following non-contact co-cultivation of slices with MMSCs.

\section{Evaluation of Rip, GFAP and Iba-1 positive glia in brain slice culture}

The next step in the study was the estimation of oligodendrocytes in the zone of lateral ventricles with corpus callosum of brain slices culture. Immunohistochemical analysis was performed 48 $h$ after treatments, when the impact on the viability (by the LDH levels) was the strong pronounced. It was found that the non-contact co-culturing the brain slices with MMSCs after PVLmiv increased Rip-immunoreactivity of the brain slices compared to PVLmiv group (1.9 \pm 0.4 a.u. vs. 4.0 \pm 1.1 a.u., respectively), but did not reach control values $-5.9 \pm 1.1$ a.u.) (Fig. 3, A1-A4).

Evaluation of GFAP and Iba-1 positive immunostaining (markers of astrocytes and microglia, respectively) in the brain slice cultures revealed that PVLmiv resulted in an increase of the integrated density of corresponding fluorescent signal (GFAP+, Iba-1+) comparing to control group. In case of astrocytes, the integrated density of GFAP-positive signal

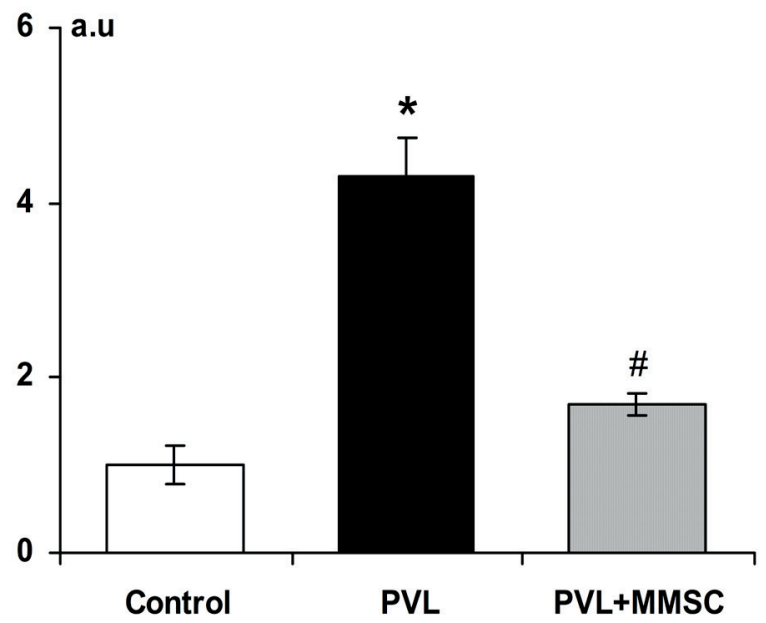

Figure 2. The relative amount of LDH enzyme in the culture medium of brain slices 48 hours after PVLmiv alone or in combination with non-contact MMSCs co-culture. Note: * statistically significant difference compared with control $(\mathrm{P}<$ $0.05)$, \# - statistically significant difference compared with PVLmiv $(\mathrm{P}<0.05)$ 
increased from $5.8 \pm 0.7$ a.u. in control group to $15.8 \pm 0.7$ a.u. 48 hours after PVLmiv. The integrated fluorescence density of Iba-1-positive microglial cells increased from $5.5 \pm 0.9$ a.u. in control group to $18.6 \pm 0.7$ a.u. 48 hours after PVLmiv (Fig. 3, B2, C2).

Immunohistochemical analysis revealed that the non-contact co-culturing of brain slices with MMSCs after PVLmiv decreased the GFAP and Iba-1 immunopositive signals comparing to PVLmiv group (Fig. 3, B3, C3). The integrated density of GFAP and Iba-1 positive fluorescence was $9.2 \pm 0.8$ a.u. and $11.6 \pm 1.3$ a.u., respectively (Fig. 3, B4, C4).

Thus oligodendrocyte damage and reactive astro- and microgliosis were reduced in noncontact co-culture brain slices with MMSCs after PVLmiv.

\section{DISCUSSION}

Multipotent mesenchymal stromal cells are considered to be a promising source of cells in regenerative medicine due to their reparative, regenerative, and modulatory properties [13]. MMSCs are good candidates for the treatment of many diseases of the central nervous system, have a strong safety profile and demonstrated good effects in improving functional result through mechanisms implicated in brain plasticity such as neurogenesis, axonal sprouting, and angiogenesis [14].

Our previous study has demonstrated that administration of MMSCs to animals with PVL model contributes to the improvement of behavioral responses and recovers cytoarchitectonics of damaged brain [11]. However, this model did not allow us to distinguish if positive effects are mediated by direct MMSCs presence in the affected brain region, and partial substitution of damaged cell population or by distant impact through released biomodulators, or both. In the current study, we applied novel PVL model in vitro using brain slice cultures [15] and investigated protective capacity of adipose-derived MMSCs in non-contact co-culture.
Organotypic brain slices culture is useful object for modeling PVL and exploring the response of nervous tissue to potential neuroprotective agents including stem cells. The cultured brain slices retain tissue organization, cell-to-cell contacts and synaptic organization similar to the in vivo environment [16, 17]. The organotypic culture provides an easy access to the extracellular space allowing better control over experimental conditions and direct impact on tissue by various substances of desired concentration [18]. This experimental system can be useful during the research of contact as well as non-contact (humoral) interaction of stem cells with tissue.

Previously we showed that, in addition to the hypoxic-ischemic injury of neural tissue, neuroinflammation is a required component in the development of PVL model in vivo [11]. For PVL modeling in vitro on brain slices we applied OGD and endotoxin (LPS) to imitate hypoxicischemic conditions and neuroinflammation. As revealed cell viability assay based on estimation of cytosolic LDH in culture medium, combined effect of these harmful factors resulted in the significant cellular damage in 48 hours after the PVLmiv (Fig. 2). MMSCs showed significant protective effect on brain slices at non-contact co-culture increasing the cell survival.

As is well known, the periventricular leukomalacia is characterized by injury of myelinated nerve fibers mostly of the corpus callosum [19]. Therefore, in our study the immunohistochemical analysis of oligodendrocytes in organotypic brain slices culture in the zone of lateral ventricles with corpus callosum was carried out. We have shown that Rip-immunoreactivity of oligodendrocytes was increased in the co-culture brain slices and MMSCs in comparison to PVLmiv group.

It has been shown that glial cells become activated in response to many CNS pathologies, such as trauma, stroke, etc. [20]. Activation of glial cells has been recognized as the primary component and hallmark of neuroinflammation [21]. Astrocytes and microglia are major players in the inflammatory response. Upon activation, 
glial cells respond to pro-inflammatory cytokines with an increase in proliferation, change of phenotypes, phagocytosis and release of a battery of pro-inflammatory molecules like
iNOS, COX-2, interleukins (IL-1, IL-6) and pro-inflammatory cytokines like TNF- $\alpha$ [22]. Up-regulation of glial intermediate filament is an important step in glial activation and the
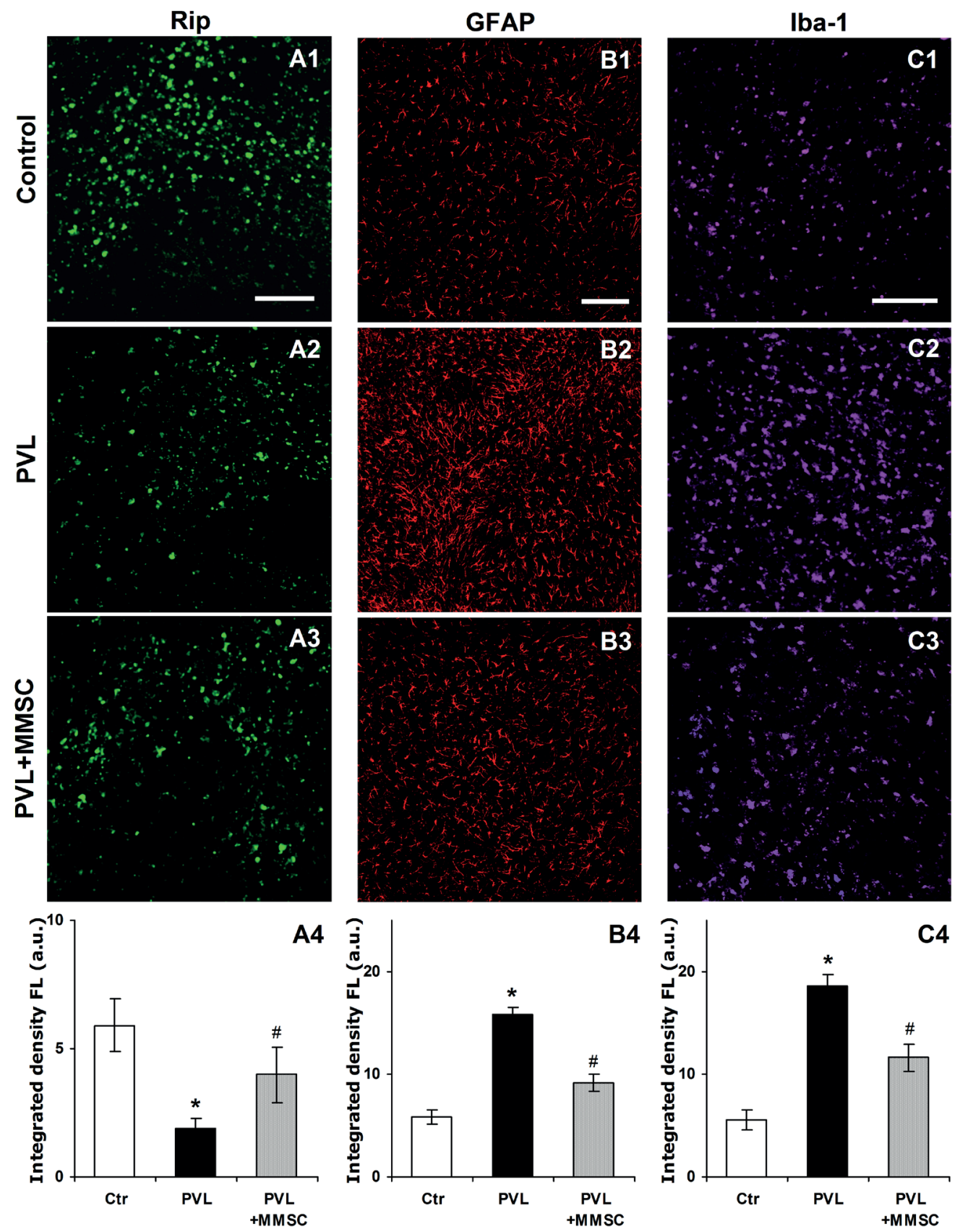

Figure 3. Confocal images of brain slices in control (A1, B1, C1), 48 hours after PVLmiv (A2, B2, C2) and PVLmiv and MMSCs co-culture (A3, B3, C3). A1-A4 - oligodendrocytes (marker Rip - green); B1-B4 - astrocytes (marker GFAP - red) and C1-C4 - microglia (marker Iba-1 - violet/pseudocolor) in brain slice culture of mouse. Scale bar - $500 \mu \mathrm{m}$. A4, B4, C4 - histogram of integrated fluorescence density. a.u. - arbitrary units. Note: ${ }^{*}$ - statistically significant difference compared with control $(\mathrm{P}<$ 0.05), \# - statistically significant difference compared with PVLmiv $(\mathrm{P}<0.05)$ 
enhancement of these proteins is the best-known hallmark of reactive gliosis [23, 24].

In PVL model in vivo, we have shown that it is accompanied by a pronounced reactive gliosis [11]. Therefore, to assess astro- and microgliosis in PVLmiv, we performed immunohistochemical study of the brain slices using antibodies to markers of astrocytes (GFAP) and microglial cells (Iba-1). We found that after $48 \mathrm{~h}$ after PVLmiv astrocytic GFAP and microglial Iba-1 immunoreactivity were significantly increased compared to the control brain slices. The noncontact co-cultivating of murine brain slices with MMSCs following the PVLmiv resulted in decrease of reactive gliosis.

Earlier studies were based on the hypothesis that the neuroprotective effects of MMSCs are caused by the replacement of damaged cells by differentiation of transplanted MMSCs into neurons or glial cells $[25,26]$. However, the current studies prefer a model of regeneration induced by the secretion of a variety of cytokines, chemokines, growth and trophic factors [27-30]. There is evidence that the MMSCs has neuroprotective potential via a modulatory mechanisms by secreting anti-inflammatory molecules [31-33]. Our data are consistent with previous reports, suggesting that the observed effects were mediated by MMSCs-secreted protective factors, as brain slices and MMSCs did not have direct contact.

\section{CONCLUSIONS}

In the current study, we demonstrate that the PVLmiv resulted in a significant release of the LDH into the culture medium, decrease of Rip-immunoreactivity and pronounced gliosis that imitate the damage of the white matter and neuroinflammation of the brain. These effects were ameliorated to a significant extent following non-contact co-culture of brain slices with MMSCs. Our data suggest that protective capacity of MMSCs can be executed distantly, evidently via released biomodulatory compounds.
The novel PVL model developed on cultured murine organotypic brain slices represents a useful tool for further dissection of the the pathogenic mechanisms underlying this brain lesion and search of new neuroprotective approaches, including of MMSCs.

The authors of this study, O. Tsupykov, I. Lushnikova, A. Ustymenko, V. Kyryk, Y. Nikandrova, M. Patseva, K. Yatsenko, G. Butenko, G. Skibo, confirm that the research and publication of the results were not associated with any conflicts regarding commercial or financial relations, relations with organizations and/or individuals who may have been related to the study, and interrelations of co-authors of the article.

\section{О. Цупиков ${ }^{1,2}$, І. Лушнікова ${ }^{1}$, А. Устименко ${ }^{2}$, В. Кирик ${ }^{2}$, Є. Нікандрова ${ }^{1}$, М. Пацева ${ }^{1}$, К. Яценко ${ }^{1}$, Г. Бутенко ${ }^{2}$, Г. Скибо ${ }^{1,2}$ \\ ВПЛИВ МУЛЬТИПОТЕНТНИХ МЕЗЕНХІ- МАЛЬНИХ СТРОМАЛЬНИХ КЛІТИН НА ЗРІЗИ ГОЛОВНОГО МОЗКУ 3 МОДЕЛЛЮ ПЕРИВЕНТРИКУЛЯРНОЇ ЛЕЙКОМАЛЯЦЇ IN VITRO ПРИ ÏХ СПIВКУЛЬТИВУВАННІ}

$\mathrm{У}$ цій роботі була використана in vitro модель перивентрикулярної лейкомаляції (ПВЛ), в якій органотипові зрізи головного мозку миші піддавали киснево-глюкозній депривації (КГД) та дії ендотоксину ліпополісахариду (ЛПС). Такий підхід дав можливість змоделювати важливі патогенетичні фактори, відповідальні за ПВЛ, - гіпоксично-ішемічний компонент і запалення. Були оцінені віддалені ефекти мультипотентних мезенхімальних стромальних клітин (ММСК) на зрізи головного мозку при їх безконтактному співкультивуванні на in vitro моделі ПВЛ. Життєздатність клітин оцінювали вимірюванням вмісту цитоплазматичного ферменту лактатдегідрогенази (ЛДГ), що вивільняється в культуральне середовище. Гліальну реакцію в перивентрикулярних ділянках культивованих зрізів мозку аналізували імуногістохімічно з використанням специфічних антитіл до маркерів олігодендроцитів, астроцитів та мікроглії (Rip, GFAP i Iba-1 відповідно). Було показано, що ПВЛ призводить до значного вивільнення цитозольного ферменту ЛДГ у культуральне середовище, що свідчить про істотне пошкодження клітин. Зниження Rip-імунореактивності відображає зменшення популяції олігоденроцитів, у той час як збільшення GFAP- i Iba-1-імунореактивності вказує на виражений астро- i мікрогліоз. Наявність ММСК у співкультурі зменшувало 
пошкоджувальні ефекти ПВЛ, підвищуючи життєздатність клітин, запобігаючи деградації олігодендроцитів і значному астро- та мікрогліозу в культивованих зрізах головного мозку. Отримані результати свідчать про те, що захисна здатність ММСК може виконуватися дистанційно швидше за все через секрецію біологічно активних речовин.

Ключові слова: перивентрикулярна лейкомаляція; культура зрізів головного мозку; киснево-глюкозна депривація; ліпополісахариди; мультипотентні мезенхімальні стромальні клітини.

${ }^{1}$ Інститут фізіології ім. О. О. Богомольия Національної академії наук України, Київ;

${ }^{2} Д У$ «Інститут генетичної та регенеративної медииини Національної академії медичних наук України», Київ; e-mail: tsupykov@gmail.com

\section{О. Цупиков, И. Лушникова, А. Устименко, В. Кирик, Е. Никандрова, М. Пацева, Е. Яценко, Г. Бутенко, Г. Скибо}

\section{ВЛИЯНИЕ МУЛЬТИПОТЕНТНЫХ МЕЗЕН- ХИМАЛЬНЫХ СТРОМАЛЬНЫХ КЛЕТОК НА СРЕЗЫ ГОЛОВНОГО МОЗГА С МОДЕЛЬЮ ПЕРИВЕНТРИКУЛЯРНОЙ ЛЕЙКОМАЛЯЦИИ IN VITRO ПРИ ИХ КО- КУЛЬТИВИРОВАНИИ}

Мультипотентные мезенхимальные стромальные клетки (ММСК) продемонстрировали терапевтический эффект после их трансплантации на in vivo модели перивентрикулярной лейкомаляции (ПВЛ). Однако механизмы, с помощью которых трансплантированные ММСК способствуют выживанию клеток и/или их функциональному восстановлению, остаются неопределенными. В этой работе была использована in vitro модель ПВЛ, в которой органотипические срезы головного мозга мыши подвергались кислород-глюкозной депривации (КГД) и действию эндотоксина липополисахарида (ЛПС). Такой подход позволил смоделировать важные патогенетические факторы, ответственные за ПВЛ, - гипоксически-ишемический компонент и воспаление. Были оценены отдаленные эффекты ММСК на срезы головного мозга при их бесконтактном кокультивировании на in vitro модели ПВЛ. Жизнеспособность клеток оценивали путем измерения цитоплазматического фермента лактатдегидрогеназы (ЛДГ), высвобождаемой в культуральную среду. Глиальную реакцию в перивентрикулярных участках культивируемых срезов мозга анализировали иммуногистохимически с использованием специфических антител к маркерам олигодендроцитов, астроцитов и микроглии (Rip, GFAP и Iba-1 соответственно). Было показано, что ПВЛ приводит к значительному высвобождению цитозольного фермента ЛДГ в культуральную среду, что свидетельствует о существенном повреждении клеток. Снижение Rip-иммунореактивности отражает уменьшение популяции олигоденроцитов, в то время как увеличение GFAP- и Iba-1-иммунореактивности указывает на выраженный астро- и микроглиоз. Присутствие ММСК в кокультуре уменьшало повреждающие эффекты ПВЛ, повышая жизнеспособность клеток, предотвращая деградацию олигодендиоцитов и обширный астро- и микроглиоз в культивируемых срезах головного мозга. Полученные данные свидетельствуют о том, что защитная способность ММСК может выполняться дистанционно, скорее всего, путем секреции биомодулирующих веществ. Ключевые слова: перивентрикулярная лейкомаляция; культура срезов головного мозга; кислород-глюкозная депривация; липополисахариды; мультипотентные мезенхимальные стромальные клетки.

\section{REFERENCES}

1. Blumenthal I. Periventricular leukomalacia: a review. Eur J Pediatr. 2004; 163 (8): 435-42.

2. Khwaja O, Volpe JJ. Pathogenesis of cerebral white matter injury of prematurity. Arch Dis Child Fetal Neonatal Ed. 2008; 93 (2): F153-161. doi: 10.1136/adc.2006.108837.

3. Gano D, Andersen SK, Partridge JC, et al. Diminished white matter injury over time in a cohort of premature newborns. J Pediatr. 2015; 166 (1): 39-43. doi: 10.1016/j. jpeds.2014.09.009.

4. Volpe JJ. Brain injury in premature infants: a complex amalgam of destructive and developmental disturbances. Lancet Neurol. 2009; 8 (1): 110-24. doi: 10.1016/S14744422(08)70294-1.

5. Borghesi A, Cova C, Gazzolo D, et al. Stem cell therapy for neonatal diseases associated with preterm birth. J Clin Neonatol. 2013; 2 (1): 1-7. doi: 10.4103/22494847.109230.

6. Chen LX, Ma SM, Zhang P, et al. Neuroprotective effects of oligodendrocyte progenitor cell transplantation in premature rat brain following hypoxic-ischemic injury. PLoS One. 2015; 10 (3): e0115997. doi: 10.1371/journal. pone.0115997.

7. Chang YS, Ahn SY, Sung S, et al. Stem cell therapy for neonatal disorders: prospects and challenges. Yonsei Med J. 2017; 58 (2): 266- 71. doi: 10.3349/ymj.2017.58.2.266.

8. Syed FI, Couriel DR, Frame D, et al. Central nervous system complications of hematopoietic stem cell transplant. Hematol Oncol Clin North Am. 2016; 30 (4): 887-98. doi: 10.1016/j.hoc.2016.03.009.

9. Vadori M, Denaro L, D'Avella D, et al. Indications and prospects of neural transplantation for chronic neurological diseases. Curr Opin Organ Transplant. 2016; 21 (5): 490-96. doi: 10.1097/MOT.0000000000000344.

10. Rustad KC, Gurtner GC. Mesenchymal stem cells home to sites of injury and inflammation. Adv Wound Care (New Rochelle). 2012; 1 (4): 147-52.

11. Tsupykov OM, Kyryk VM, Ustymenko AM, et al. Effect of transplantation of adipose-derived multipotent mesenchymal stromal cells on the nervous tissue and behavioral responses in a mouse model of periventricular leukomalacia. Cell and Organ Transplantology. 2015; 3 (1): 68-73. 
12. Dominici M, Le Blanc K, Mueller I, et al. Minimal criteria for defining multipotent mesenchymal stromal cells. The International Society for Cellular Therapy position statement. Cytotherapy. 2006; 8 (4): 315-17.

13. Zachar L, Bačenková D, Rosocha J. Activation, homing, and role of the mesenchymal stem cells in the inflammatory environment. J Inflamm Res. 2016; 9: 231-40. doi: 10.2147/JIR.S121994.

14. Vu Q, Xie K, Eckert M, et al. Meta-analysis of preclinical studies of mesenchymal stromal cells for ischemic stroke. Neurology. 2014; 82: 1277-86. doi: 10.1212/ WNL.0000000000000278.

15. Tsupykov OM, Lushnikova IV, Nikandrova YA, et al. A novel model of periventricular leukomalacia on mouse organotypic brain slice culture. Cell and Organ Transplantology. 2016; 4 (2): 188-93. doi:10.22494/cot. v4i2.60.

16. Morin-Brureau MM, De Bock F, Lerner-Natoli M. Organotypic brain slices: a model to study the neurovascular unit micro-environment in epilepsies. Fluids Barriers CNS. 2013; 10 (1): 11. doi: 10.1186/2045-8118-10-11.

17. Wilhelmi E, Schöder UH, Benabdallah A, et al. Organotypic brain slice cultures from adult rats: approaches for a prolonged culture time. Altern Lab Anim. 2002; 30 (3): 275-83.

18. Humpel C. Organotypic brain slice cultures: a review. Neuroscience. 2015; 305: 86-98. doi: 10.1016/j.neuroscience.2015.07.086.

19. Deng W, Pleasure J, Pleasure D. Progress in periventricular leukomalacia. Arch Neurol. 2008; 65 (10): 1291-295. doi: 10.1001/archneur.65.10.1291.

20. Verkhratsky A, Parpura V, Pekna M, et al. Glia in the pathogenesis of neurodegenerative diseases. Biochem Soc Trans. 2014; 42 (5): 1291-1301. doi: 10.1042/ BST20140107.

21. Gualtierotti R, Guarnaccia L, Beretta M, et al. Modulation of neuroinflammation in the central nervous system: role of chemokines and sphingolipids. Adv Ther. 2017; 34 (2): 396-420. doi: 10.1007/s12325-016-0474-7.

22. Lucas SM, Rothwell NJ, Gibson RM. The role of inflam- mation in CNS injury and disease. Br J Pharmacol. 2006; 147 (Suppl 1): S232-40.

23. Pekny M, Pekna M. Astrocyte intermediate filaments in CNS pathologies and regeneration. J Pathol. 2004; 204: 428-37.

24. Pivneva TA, Tsupykov OM, Pilipenko MN, et al. Structural modifications of astrocytes in the hippocampus after experimental cerebral ischemia in gerbils. Neurophysiology. 2005; 37 (5): 359-64.

25. Chen X, Katakowski M, Li Y, et al. Human bone marrow stromal cell cultures conditioned by traumatic brain tissue extracts: growth factor production. J Neurosci Res. 2002; 69: 687-91.

26. Woodbury D, Schwarz EJ, Prockop DJ, et al. Adult rat and human bone marrow stromal cells differentiate into neurons. J Neurosci Res. 2000; 61: 364-70.

27. Caplan AI, Dennis JE. Mesenchymal stem cells as trophic mediators. J Cell Biochem. 2006; 98: 1076-84.

28. Marconi S, Castiglione G, Turano E, et al. Human adiposederived mesenchymal stem cells systemically injected promote peripheral nerve regeneration in the mouse model of sciatic crush. Tissue Eng Part A. 2012; 18: 1264-72. doi: 10.1089/ten.TEA.2011.0491.

29. Rivera FJ, Aigner L. Adult mesenchymal stem cell therapy for myelin repair in multiple sclerosis. Biol Res. 2012; 45: 257-68. doi: 10.4067/S0716-97602012000300007.

30. Wagner W, Roderburg C, Wein F, et al. Molecular and secretory profiles of human mesenchymal stromal cells and their abilities to maintain primitive hematopoietic progenitors. Stem Cells. 2007; 25: 2638-47.

31. Uccelli A, Moretta L, Pistoia V. Mesenchymal stem cells in health and disease. Nat Rev Immunol. 2008; 8: 726-36. doi: 10.1038/nri2395.

32. Uccelli A, Pistoia V, Moretta L. Mesenchymal stem cells: A new strategy for immunosuppression? Trends Immunol. 2007; 28: 219-26.

33. Zhang J, Li Y, Zheng X, et al. Bone marrow stromal cells protect oligodendrocytes from oxygen-glucose deprivation injury. J Neurosci Res. 2008; 86: 1501-10. doi: 10.1002/jnr.21617.

Received 14.06.2017 